\title{
Patterns of use of time by family caregivers of elderly persons with dementia
}

Elcyana Bezerra Carvalho' 1 D Anita Liberalesso Neri' $\mathbb{1}$

\section{Abstract}

Objectives: to describe patterns of use of time in family caregivers of elderly people with dementia, considering the characteristics of the caregivers, the care recipients and the context. Method: Fifty family caregivers of elderly people with intermediate and high levels of physical and cognitive disability participated in an interview about time spent on obligatory care activities over four periods of six hours during a 24-hour period. In addition, a questionnaire about social activities, scales of physical and cognitive functionality of the elderly and an inventory of burden in the family caregivers were applied. Results: $88.0 \%$ of the caregivers were women, with a mean age of 57.9 ( \pm 11.2 ) years; $45.92 \%$ of the time of the caregivers was used in care activities, $36.92 \%$ in discretionary activities, $31.17 \%$ in recuperation, and $25.67 \%$ in the obligatory activities of the life of the caregiver. The greater the dependence, the longer the care, the less time for selfcare and greater the caregivers' subjective burden. Conclusion: The level of dependence of elderly persons affected by dementia results in an increase in caregiving time and competes with other activities performed by the caregiver. Reorganization of the use of time by family caregivers and provision of formal support can reduce the caregiving burden and benefit the well-being of caregivers.

\footnotetext{
Universidade Estadual de Campinas, Faculdade de Ciências Médicas, Programa de Pós-graduação em Gerontologia. Campinas, São Paulo, Brasil.

Funding: Coordenadoria de Aperfeiçoamento de Pessoal do Ensino Superior (CAPES), por meio de bolsa de doutorado (processo no 01P-3489/2014).

Keywords: Time; Caregivers; Dependency; Activities of Daily Living; Long-term Care. Alzheimer Disease. 


\section{INTRODUCTION}

The first studies on the use of time by family caregivers were conducted by Moss et al. ${ }^{1}$ and were based on the time budgets methodology, which involves the daily estimating of time spent on activities. While used in industrial and commercial organizations, the methodology was unknown in the context of the formal (provided by professionals) and informal (provided by relatives or other volunteers) care of the elderly. The authors created a situation where, through a "Yesterday Interview", information was obtained on when, where, with whom, for how long, and what activities were performed by caregivers in a 24 -hour period prior to the interview. The data were recorded in a matrix that covered the 24 hours of the day, subdivided into 96 periods of 15 minutes, and then tabulated within the following classes created in a parallel study conducted by Moss and Lawton ${ }^{2}$ : activities of instrumental assistance such as cleaning the house and preparing food, as well as personal care such as bathing and toilet use, provided to the elderly care recipient; activities that were obligatory (self-care, work and care for the home and family) and discretionary activities in the caregivers'life (active and passive leisure and rest).

Further research has shown that family caregivers devote more time to protection and instrumental assistance than formal caregivers ${ }^{3,4}$. Most family caregivers are spouses or daughters of the care recipients, do not perform paid work outside home, have low levels of schooling, reside with the care recipient, and are the sole or main caregivers ${ }^{5-7}$, possibly assisted by relatives and friends. The presence of these secondary caregivers tends to cause distortions in estimates of the use of time of primary caregivers $^{3,8}$. In Brazil, the role of domestic workers in the care of dependent elderly persons tends to be seen as part of domestic chores, which is another source of distortion?.

The time devoted to basic activities of daily living (BADL) and instrumental activities of daily living (IADL) and the time spent on supervision increases proportionally with the worsening of dementia $a^{10,11}$. Thus, as the number of people affected by dementia in the population increases, there is a greater need for informal care and the creation of informal support networks ${ }^{12}$.
Time spent on obligatory care activities restricts the participation of informal caregivers in discretionary activities, including social activities outside home, such as religious activities and work, and at-home activities such as reading and communication with friends and relatives through social networks. Two of the most recurrent complaints of family caregivers are the deprivation and the sense of loss of control over one's own social life ${ }^{13}$. Obligatory care activities are the most time consuming, ${ }^{14,15}$ generating dissatisfaction with the constraints they place on personal, domestic and social activities ${ }^{16}$, and are most associated with depressive symptoms and with a sense of lack of social support ${ }^{17}$. Caregivers perceive restrictions on their leisure activities as stressful and onerous, but their participation in social group activities can mitigate the negative effects of caregiving $^{18}$.

The objective burden of family caregivers of elderly people with dementia is associated with the progression of the disease and with increased physical and cognitive dependence, the neuropsychiatric problems of the care recipient and the great number of hours needed for direct care and supervision ${ }^{11,19,20}$. The subjective burden is associated with depression and emotional distress, with a sense of unmet needs and restrictions on the daily time available for selfcare, social participation, family commitments, and paid work ${ }^{4,15,21}$. Clinical, psychosocial, and educational interventions aimed at managing the time spent on care can mitigate the impact of caring for elderly persons with dementia on the well-being of caregivers.

Currently, there are no data on the schedules of time dedicated to obligatory activities of care, personal and family life and discretionary activities by Brazilian family caregivers of elderly people with dementia. Bauab and Emmel ${ }^{22}$ focused occupational and motivational aspects of the use of time by formal caregivers, and not those concerning the provision of care within the family.

The management of time by family caregivers of elderly people with physical and cognitive dependencies is an important element in determining the quality of care and the well-being of both the elderly care recipients and the family caregivers. The use of a valid methodology can benefit the reliability 
of the data regarding the phenomenon. The purpose of the present study was to describe patterns of the use of time by caregivers of elderly people with dementia and to investigate relationships between these patterns and characteristics of the caregivers, the care recipients, and the context of care.

\section{METHOD}

A descriptive study was carried out with a convenience sample composed of 50 family caregivers of elderly people with dementia assisted at the Integrated Medical Care Center of the University of Fortaleza (NAMI/UNIFOR, Brazil) and at the Brazilian Alzheimer's Association Ceará Region (ABRAz-CE) support service, who agreed to participate in the study, whose data collection occurred form May to July 2017. The inclusion criteria for caregivers were: age 50 or older; be a spouse, son or daughter or other relative of an elderly person diagnosed with dementia by a physician, in accordance with the terms of the medical records; reside with the elderly recipient of care and be the primary caregiver. The exclusion criteria were: cognitive, sensory, comprehension and communication impairments that made the participation of the caregivers in the interview unfeasible, according to the judgment of three trained recruiters (two students of a specialization course in Gerontology and the researcher). The caregivers were recruited in person or by telephone, always with the consent of the directors of the services.

Use of time: to measure the dependent variable a semi-structured interview was organized, according to the "Yesterday Interview" proposed by Moss et al, 1993. The interviewer followed a script in which the daily activities of the caregiver, grouped in obligatory and discretionary of the caregivers'life, oblicatory of care, and recovery, were presented in a printed time matrix with four 6 -hour periods (morning, afternoon , night and dawn), with appointment of each hour.A script was drawn up in which the activities of the caregiver, grouped into the classes obligatory for care, obligatory in the life of the caregivers, discretionary and recuperation, were presented in a printed matrix of time, with four periods of six hours each (morning, afternoon, night and early hours). The care provided to the elderly included: physical care (bathing, giving food, giving medicine, taking to the bathroom, dressing and tidying up); social and emotional support (reading, talking, praying together, keeping company, and helping to organize the belongings of care recipients). Activities relevant to the life of the caregivers included: self-care (eating, hygiene, beauty and physical exercises inside and outside the home) and family life (domestic activities, taking care of grandchildren, shopping for daily needs, cooking, washing, ironing, sweeping, and caring for animals and plants). Discretionary activities included: personal life (leisure, art, crafts and religious, TV, reading, solitary games, praying and meditating) and social life (phoning, chatting, writing e-mails and receiving visits, making visits, attending meetings, restaurants, cinema, church, , courses, classes and shopping centers). The recuperation activities included rest and sleep.

Contextualization of care in the family environment: Through self-reported items the following characteristics were assessed: the age and gender of the elderly care recipients; the degree of kinship between the caregivers and the elderly persons with dependencies (spouse, father or mother, father-in-law or mother-in-law, grandparent or other relative); availability of practical help, domestic workers, daytime, night and weekend companions, and home support services. All items were dichotomous in nature.

Conditions of dependency of the elderly care recipients: the main medical diagnosis of the elderly care recipients (through an open item), their level of physical dependence, measured by the Pfeffer Questionnaire of Functional Activities ${ }^{23-25}$ and their level of cognitive dependence, assessed by the Clinical Dementia Rating (CDR $)^{26-27}$. These two scales are commonly applied to surrogate informants when the level od dependence of the elderly impairs their ability to respond. The Pfeffer Scale consists of ten items that evaluate independencebased functionality to perform instrumental activities of daily living (controlling one's finances; shopping; heating water and turning off the oven; preparing meals; keeping up to date; watching and discussing the news; remaining orientated when moving around the neighborhood; remembering appointments; taking care of own medication and staying home alone ${ }^{24}$. Each item is scored from 
zero (independence) to three (dependency), with higher values indicating greater dependence. The reliability and reproducibility of the instrument was demonstrated by a psychometric study involving Brazilian elderly persons ${ }^{25}$. The CDR comprises six cognitive-behavioral categories: memory, orientation, judgment or problem solving, community relations, home or leisure activities personal care. Each category was scored from zero to three points $(0=$ no change, $0.5=$ questionable dementia, $1=$ mild dementia, $2=$ moderate dementia and $3=$ severe dementia), except for the personal care category, which did not include the score 0.5 . The memory category received the most weight in the evaluation 26,27 . The final classification of the CDR is obtained by the analysis of the classifications by categories, following a set of rules elaborated and validated by Morris $^{26}$. The instrument does not include cut-off scores based on population performance, since the results of the elderly are compared to the scores they obtained in the past.

Perceived burden as a result of the provision of care: this was assessed using the Zarit Burden Scale ${ }^{28,29}$, which consists of 22 items with five points each (from $0=$ never to $4=$ always), assessing the level of perceived burden of the caregiver with regard to health, personal and social life, financial situation, emotional well-being and interpersonal relationships. The instrument generates a total score ranging from 0 to 88 . In Brazil, Scazufca ${ }^{29}$ performed the translation and semantic-cultural validation of the instrument using data from samples of caregivers of elderly people with mood and other psychiatric disorders. The Cronbach's alpha index, an indicator of internal consistency, was 0.87 . The distribution was divided by terciles ( $\leq 32,33$ to 56 and $\geq 57$ points), indicating low, moderate and high burden.

Social activities performed outside home by caregivers: these were evaluated by eight dichotomous items specifically designed for the study: (a) go to hairdresser, manicurist, physiotherapy or the gym, or make purchases for oneself; (b) go to church or temple for religious services or participate in religious activities or groups; (c) attend social events, parties and meetings; (d) go to cultural events, such as concerts, shows, and exhibitions, the movies and the theater; (e) participate in meetings of boards or councils or carry out political activities; ( $f$ ) attending courses or participating in social (g) take short trips (day or weekend); (h) visiting.

Sociodemographic characteristics of caregivers: gender (male or female); age indicated by date of birth; marital status (married, widower, single, divorced); performed paid work (yes or no) and years of schooling (in response to the question "up to what school year did you study?").

Formal acceptance of participation was carried out by signing a free and informed consent form, drafted in accordance with the requirements of Resolution No. 466 dated December 12, 2012, of the National Health Council (NHC), and approved by the Research Ethics Committee of the State University of Campinas, Brazil, on 06/04/2017, under approval $\mathrm{n}^{\mathrm{o}} 2.003 .545$.

Data were collected in individual face-toface interviews, chaired by one of three trained interviewers, performed at ABRAz-CE (36.0\%), NAMI/UNIFOR (62.0\%) and at the households of a group of caregivers who declared that they could not leave home or the elderly care recipient $(2.0 \%)$. All the participants were interviewed in a single session with a mean duration of $62( \pm 9.2)$ minutes. About $30 \%$ of this period was devoted to evaluations that were of interest to other surveys and were not included in this research.

The results of the Shapiro-Wilk normality test applied to the sample suggested the use of nonparametric tests. Pearson's Chi-squared test and Fisher's Exact test were used to compare the frequencies of the categorical variables according to the variabels of interest. To compare the distributions of the ordinal variables, the Mann-Whitney $U$ test for two independent samples and the Kruskal-Wallis test for three or more independent samples were used. To compare the time spent by the caregivers on the four types of activities, the Friedman and Wilcoxon tests for related samples were used. Spearman correlation analyzes were performed between the distributions of daily estimates of time in each class of activity, the results of the caregivers on the burden scale, and the scores attributed to the elderly in the Pfeffer and CDR scales. The internal consistency of the scales was measured and had Cronbach's alpha as an indicator. 


\section{RESULTS}

Most of the caregivers were women, adults, and married. The mean age was $57.9( \pm 11.2)$ years; $78.0 \%$ had nine or more years of schooling; $77.6 \%$ did not perform paid work (Table 1).

The mean age of the care recipients was $79.6( \pm$ 7.5) years. Most were sons or daughters, but $32.6 \%$ were spouses of caregivers. On average, the caregivers had provided care for $40.3( \pm 23.6)$ months. Most of the caregivers had unpaid practical help (mainly from other relatives) while only $18.0 \%$ had paid help, mostly from domestic workers $(77.0 \%)$ or from a daytime $(12.1 \%)$ or weekend companion $(10.9 \%)$. Only $4.0 \%$ had private formal home support. On average, caregivers have been performing; 2.9 social activities outside the home. Eighty-four percent of caregivers reported that the main health problem of the elderly was Alzheimer's Disease; $16.0 \%$ reported cerebrovascular diseases. At the same time, some of the care recipients had cardiovascular disease $(12.0 \%)$, diabetes mellitus (10.0\%), Parkinson's disease (4.0\%), arthrosis or rheumatism (2.0\%) or immobility (2.0\%). Most care recipients had intermediate level scores on the Pfeffer Scale, while 32.0\% scored in the upper third and $22.0 \%$ in the lower third. The distribution of CDR scores followed a similar trend: $22.0 \%$ were rated as having questionable or mild dementia and $78.0 \%$, moderate to severe dementia. Most caregivers had moderate (33-56) or high $(\geq 57)$ scores on the burden scale. The functional independence ${ }^{23-25}$, stage of dementia ${ }^{26,27}$ and perceived burden ${ }^{28,29}$ subscales exhibited high internal reliability, indicated by Cronbach's alphas of $0.935,0.947$ and 0.872 , respectively (Table 2).

The caregivers reported that on average they spent 11.02 hours of the day providing direct care to the elderly, 8.86 hours in discretionary activities and 6.16 hours in obligatory activities related to their own life, such as care of the home. An average of 7.48 hours were dedicated to rest or recuperation activities. In other words, caregivers spent $45.92 \%$ of their daily time on care activities for the elderly; $36.92 \%$ on discretionary and, $25.67 \%$ on obligatory activities from their own lives, and $31.17 \%$ on recuperation activities. The data showed simultaneity in the performance of the caregivers activities. The caregivers spent more time on direct care for the elderly and on obligatory activities of their own lives in the morning and afternoon. Discretionary activities were conducted mainly at night. In the early hours, caregivers spent most of their time resting and caring. . In terms of both total hours of care during the day and the time each day proportionally reserved for the various types of activities, the highest values were for care of the elderly and discretionary activities. Table 3 shows the results of the comparisons between the amount of time dedicated to the different classes of activities each day. A statistical penalization procedure (Bonferroni correction) was adopted for the Wilcoxon test, in order to reduce the possibility of the occurrence of significant differences by chance.

The duration of the activities were compared considering the characteristics of the caregivers, the conditions of the context of care and the characteristics of the elderly care recipients. Women, caregivers who did not work, and those without paid support provided care for more hours in the morning than male caregivers and caregivers who worked. Caregivers of the elderly who were neither spouses nor sons or daughters spent more time on discretionary activities than those who cared for a parent or spouse. Caregivers of parents reported spending more time than caregivers of spouses and other relatives on obligatory activities from their own lives. Caregivers of parents spent more time providing care than caregivers of spouses or other relatives. In the afternoon, those who cared for their parents and those who were responsible for elderly persons with greater physical and cognitive disabilities spent significantly longer periods providing care than those who cared for a spouse or other relative and those who cared for more independent elderly persons. Caregivers with lower perceived burden spent more time resting than their peers who report greater burden (Table 4).

Although the correlation indicators were not high, it was observed that the higher the caregiver burden score and the higher the scores of the elderly care recipients on the Pfeffer and CDR scales, the more time the caregivers spent on care activities for the elderly. No other statistically significant correlations were observed (Table 5). 
Table 1. Sociodemographic characteristics of caregivers. Fortaleza, Ceará, Brazil, 2017.

\begin{tabular}{llll}
\hline Variables & Conditions & $\mathrm{n}(\%)$ & Mean (standard deviation) \\
\hline Gender & Male & $6(12.0)$ & ---- \\
& Female & $44(88.0)$ & \\
Marital status & Married & $22(44.0)$ & ---- \\
& Single & $19(38.0)$ & \\
& Divorced & $6(12.0)$ & \\
Age & Widowed & $3(6.0)$ & $57.9( \pm 11.2)$ \\
& $<40-59$ & $29(58.0)$ & \\
& $60-69$ & $10(20.0)$ & $11.6( \pm 3.7)$ \\
Years of schooling & 70 years + & $11(22.0)$ & \\
& 1 to 4 & $2(4.0)$ & \\
\hline Paid work & 5 to 8 & $9(18.0)$ & ---- \\
& 9 or more & $39(78.0)$ & \\
\hline
\end{tabular}

Table 2. Characterization of the context of care. Fortaleza, Ceará, Brazil, 2017.

\begin{tabular}{|c|c|c|c|}
\hline Variables & Conditions & $\mathrm{n}(\%)$ & Mean (sd) \\
\hline \multirow[t]{3}{*}{ Age of care recipients } & $60-69$ & $6(12.0)$ & $79.6( \pm 7.5)$ \\
\hline & $70-79$ & $18(36.0)$ & \\
\hline & 80 or more & $26(52.0)$ & \\
\hline \multirow[t]{3}{*}{ Relationship between caregivers and care recipients } & Spouse & $16(32.6)$ & ---- \\
\hline & Parents & $28(57.2)$ & \\
\hline & Other relatives & $5(10.2)$ & \\
\hline \multirow[t]{2}{*}{ Receive unpaid help } & Yes & $33(66.0)$ & ---- \\
\hline & No & $17(34.0)$ & \\
\hline \multirow[t]{2}{*}{ Receive professional help } & Yes & $9(18.0)$ & ---- \\
\hline & No & $41(82.0)$ & \\
\hline Number of activities carried out by & 0 & $1(2.0)$ & $2.9( \pm 1.7)$ \\
\hline \multirow[t]{2}{*}{ caregivers outside the home } & 1 to 3 & $34(68.0)$ & \\
\hline & 4 to 8 & $15(30.0)$ & \\
\hline \multirow[t]{3}{*}{ Pfeffer Scale scores of care recipients } & $<22$ & $11(22.0)$ & $25.3( \pm 6.9)$ \\
\hline & 23 to 29 & $23(46.0)$ & \\
\hline & $>30$ & $16(32.0)$ & \\
\hline \multirow[t]{3}{*}{ Clinical Dementia Rating (CDR) scores of care recipients } & $<9$ & $11(22.0)$ & $2.0( \pm 0.8)$ \\
\hline & 10 to 15 & $25(50.0)$ & \\
\hline & $>16$ & $14(28.0)$ & \\
\hline \multirow[t]{3}{*}{ Perceived burden scores of caregivers } & $\leq 32$ & $14(28.0)$ & $43.5( \pm 15.0)$ \\
\hline & $33-56$ & $26(52.0)$ & \\
\hline & $\geq 57$ & $10(20,0)$ & \\
\hline
\end{tabular}


Table 3. Daily schedule of time dedicated to the performance of obligatory, discretionary and recuperation activities by family caregivers of elderly people with physical and cognitive dependencies. Fortaleza, Ceará, Brazil, 2017.

\begin{tabular}{|c|c|c|c|c|}
\hline Activities & Means* (sd) & Medians & Min-Max & $\mathrm{p}^{* *}$ \\
\hline \multicolumn{5}{|l|}{ Over 24 hours } \\
\hline Obligatory care for the elderly & $11.02^{a}( \pm 3.60)$ & 10.00 & $5.00-18.00$ & \multirow[t]{4}{*}{$<0.001$} \\
\hline Discretionary & $8.86^{\mathrm{b}}( \pm 2.22)$ & 9.00 & $3.00-15.00$ & \\
\hline Obligatory in caregiver's life & $6.16^{\mathrm{c}}( \pm 4.93)$ & 6.00 & $0.00-18.00$ & \\
\hline Recuperation & $7.48^{c}( \pm 1.58)$ & 7.00 & $4.00-10.00$ & \\
\hline \multicolumn{5}{|l|}{ Morning } \\
\hline Obligatory care for the elderly & $4.12^{a}( \pm 1.69)$ & 4.50 & $1.00-6.00$ & \multirow[t]{4}{*}{$<0.001$} \\
\hline Discretionary & $2.54^{\mathrm{b}}( \pm 1.16)$ & 2.00 & $0.00-5.00$ & \\
\hline Obligatory in caregiver's life & $2.92^{\mathrm{b}}( \pm 2.19)$ & 3.00 & $0.00-6.00$ & \\
\hline Recuperation & $0.14^{\mathrm{c}}( \pm 0.35)$ & 0.00 & $0.00-1.00$ & \\
\hline \multicolumn{5}{|l|}{ Evening } \\
\hline Obligatory care for the elderly & $3.66^{\mathrm{a}}( \pm 1.73)$ & 4.00 & $0.00-6.00$ & \multirow[t]{4}{*}{$<0.001$} \\
\hline Discretionary & $2.48^{\mathrm{c}}( \pm 1.50)$ & 2.00 & $0.00-6.00$ & \\
\hline Obligatory in caregiver's life & $2.14^{\mathrm{c}}( \pm 2.21)$ & 1.00 & $0.00-6.00$ & \\
\hline Recuperation & $0.76^{\mathrm{b}}( \pm 0.69)$ & 1.00 & $0.00-2.00$ & \\
\hline \multicolumn{5}{|l|}{ Night } \\
\hline Obligatory care for the elderly & $2.66^{\mathrm{a}}( \pm 1.60)$ & 3.00 & $0.00-6.00$ & \multirow[t]{4}{*}{$<0.001$} \\
\hline Discretionary & $3.60^{\mathrm{b}}( \pm 1.20)$ & 4.00 & $1.00-6.00$ & \\
\hline Obligatory in caregiver's life & $1.10^{\mathrm{c}}( \pm 1.63)$ & 0.50 & $0.00-6.00$ & \\
\hline Recuperation & $1.32^{\mathrm{c}}( \pm 1.08)$ & 1.00 & $0.00-4.00$ & \\
\hline \multicolumn{5}{|l|}{ Early Hours } \\
\hline Obligatory care for the elderly & $0.58^{\mathrm{b}}( \pm 0.95)$ & 0.00 & $0.00-4.00$ & \multirow[t]{3}{*}{$<0.001$} \\
\hline Discretionary & $0.24^{\mathrm{b}}( \pm 0.62)$ & 0.00 & $0.00-3.00$ & \\
\hline Recuperation & $5.26^{\mathrm{a}}( \pm 1.16)$ & 6.00 & $0.00-6.00$ & \\
\hline \multicolumn{5}{|l|}{$\%$ of daily time } \\
\hline Obligatory care for the elderly & $45.92^{a}( \pm 15.00)$ & 41.67 & $20.83-75.00$ & \multirow[t]{4}{*}{$<0.001$} \\
\hline Discretionary & $36.92^{\mathrm{b}}( \pm 9.26)$ & 37.50 & $12.50-62.50$ & \\
\hline Obligatory in caregiver's life & $25.67^{\mathrm{c}}( \pm 20.54)$ & 25.00 & $0.00-75.00$ & \\
\hline Recuperation & $31.17^{\mathrm{c}}( \pm 6.59)$ & 29.17 & $29.17-41.67$ & \\
\hline
\end{tabular}

* Values of means indicated by different letters are significantly different and values indicated by the same letter are not; ** Friedman test, followed by the Wilcoxon test in pairs, with Bonferroni correction. 
Table 4. Daily schedules of time use according to characteristics of the caregivers. conditions of the context of care and characteristics of the elderly care recipients. Fortaleza. Ceará, Brazil, 2017.

\begin{tabular}{|c|c|c|c|c|c|}
\hline Variables/conditions & Activities x periods of the day & $\mathrm{n}$ & Mean (sd) & Median & $\mathrm{p}$ \\
\hline \multicolumn{6}{|l|}{ Gender of caregiver } \\
\hline Male & \multirow[t]{2}{*}{ Care of elderly person - Morning } & 6 & $2.17^{\mathrm{b}}( \pm 2.32)$ & 2.00 & \multirow[t]{2}{*}{$0.045^{*}$} \\
\hline Female & & 44 & $3.86^{\mathrm{a}}( \pm 1.56)$ & 4.00 & \\
\hline \multicolumn{6}{|c|}{ Paid work by the caregiver } \\
\hline Yes & \multirow[t]{2}{*}{ Care of elderly person - Morning } & 11 & $3.00^{\mathrm{b}}( \pm 1.73)$ & 3.00 & \multirow[t]{2}{*}{$0.020^{*}$} \\
\hline No & & 38 & $4.39^{\mathrm{a}}( \pm 1.55)$ & 5.00 & \\
\hline \multicolumn{6}{|c|}{ Help from domestic worker or paid caregiver } \\
\hline Yes & Obligatory activities in the life of the & 9 & $1.00^{\mathrm{b}}( \pm 1.66)$ & 0.00 & \multirow[t]{2}{*}{$0.005^{*}$} \\
\hline No & caregiver - Morning & 41 & $3.34^{\mathrm{a}}( \pm 2.08)$ & 4.00 & \\
\hline \multicolumn{6}{|c|}{ Relationship of caregiver with elderly care recipient } \\
\hline Spouse & \multirow{3}{*}{$\begin{array}{l}\text { Discretionary activities in the life of } \\
\text { the caregiver - Afternoon }\end{array}$} & 16 & $1.94^{\mathrm{b}}( \pm 1.24)$ & 2.00 & \multirow[t]{3}{*}{$0.016^{* *}$} \\
\hline Father/Mother & & 28 & $2.50^{\mathrm{b}}( \pm 1.40)$ & 2.00 & \\
\hline Other & & 5 & $4.40^{\mathrm{a}}( \pm 1.52)$ & 5.00 & \\
\hline Spouse & \multirow{3}{*}{$\begin{array}{l}\text { Obligatory activities in the life of the } \\
\text { caregiver - Morning }\end{array}$} & 16 & $1.81^{\mathrm{b}}( \pm 2.17)$ & 1.00 & \multirow[t]{3}{*}{$0.011^{* *}$} \\
\hline Father/Mother & & 28 & $3.64^{\mathrm{a}}( \pm 1.91)$ & 4.00 & \\
\hline Other & & 5 & $1.80^{\mathrm{b}}( \pm 2.00)$ & 1.00 & \\
\hline Spouse & \multirow{3}{*}{$\begin{array}{l}\text { Obligatory activities in the life of the } \\
\text { caregiver - Afternoon }\end{array}$} & 16 & $1.00^{\mathrm{b}}( \pm 1.63)$ & 0.00 & \multirow[t]{3}{*}{$0.029^{* *}$} \\
\hline Father/Mother & & 28 & $2.64^{\mathrm{a}}( \pm 2.18)$ & 2.00 & \\
\hline Other & & 5 & $2.20^{\mathrm{a.b}}( \pm 2.68)$ & 1.00 & \\
\hline Spouse & \multirow{3}{*}{$\begin{array}{l}\text { Obligatory activities in the life of the } \\
\text { caregiver - All }\end{array}$} & 16 & $3.50^{\mathrm{b}}( \pm 3.92)$ & 2.00 & \multirow[t]{3}{*}{$0.013^{* *}$} \\
\hline Father/Mother & & 28 & $7.36^{\mathrm{a}}( \pm 4.46)$ & 8.00 & \\
\hline Other & & 5 & $5.60^{a . b}( \pm 5.68)$ & 2.00 & \\
\hline \multicolumn{6}{|l|}{ Pfeffer Scale Score } \\
\hline$\leq 22$ & \multirow[t]{3}{*}{ Care of elderly person - Afternoon } & 11 & $2.36^{\mathrm{b}}( \pm 1.80)$ & 2.00 & \multirow[t]{3}{*}{$0.029^{* *}$} \\
\hline $23-29$ & & 23 & $3.96^{\mathrm{a}}( \pm 1.49)$ & 4.00 & \\
\hline$\geq 30$ & & 16 & $4.13^{\mathrm{a}}( \pm 1.67)$ & 4.00 & \\
\hline 22 & \multirow[t]{3}{*}{ Care of elderly person - All } & 11 & $8.82^{\mathrm{b}}( \pm 4.19)$ & 7.00 & \multirow[t]{3}{*}{$0.006^{* *}$} \\
\hline $23-29$ & & 23 & $10.83^{\mathrm{a} . \mathrm{b}}( \pm 3.24)$ & 10.00 & \\
\hline$\geq 30$ & & 16 & $12.81^{\mathrm{a}}( \pm 2.86)$ & 12.50 & \\
\hline \multicolumn{6}{|c|}{ Score of elderly care recipient in Clinical Dementia Rating (CDR) } \\
\hline $0.5-1.00$ & \multirow[t]{3}{*}{ Care of elderly person - Afternoon } & 10 & $2.30^{\mathrm{b}}( \pm 1.83)$ & 2.00 & $0.030^{* *}$ \\
\hline 2.00 & & 26 & $4.00^{\mathrm{a}}( \pm 1.47)$ & 4.00 & \\
\hline 3.00 & & 14 & $4.00^{\mathrm{a}}( \pm 1.75)$ & 4.00 & \\
\hline $0.5-1.00$ & Care of elderly person - All & 10 & $8.40^{\mathrm{b}}( \pm 3.47)$ & 7.00 & $0.007^{* *}$ \\
\hline 2.00 & & 26 & $11.23^{\mathrm{a}}( \pm 3.46)$ & 10.00 & \\
\hline 3.00 & & 14 & $12.50^{\mathrm{a}}( \pm 3.13)$ & 12.50 & \\
\hline Perceived burden of $\mathrm{c}$ & & & & & \\
\hline$\leq 32$ & Care of elderly person - Early hours & 11 & $0.45^{a . b}( \pm 0.82)$ & 0.00 & $0.031^{* *}$ \\
\hline $33-56$ & & 22 & $0.23^{\mathrm{b}}( \pm 0.53)$ & 0.00 & \\
\hline$\geq 57$ & & 10 & $1.30^{\mathrm{a}}( \pm 1.42)$ & 1.00 & \\
\hline$\leq 32$ & Recuperation - All & 11 & $8.09^{\mathrm{a}}( \pm 1.87)$ & 8.00 & $0.020^{* *}$ \\
\hline $33-56$ & & 22 & $7.77^{\mathrm{a}}( \pm 1.02)$ & 8.00 & \\
\hline$\geq 57$ & & 10 & $6.20^{\mathrm{b}}( \pm 1.55)$ & 7.00 & \\
\hline
\end{tabular}

${ }^{*} P$ values for the Mann-Whitney $U$ test, for comparison between two independent samples; ** $p$ values for the Kruskal-Wallis test, for comparison between three independent samples, followed by the Dunn test for multiple comparisons. Mean values indicated by different letters are significantly different. 
Table 5. Correlations between the values of use of time, caregiver burden, and physical and cognitive functioning of care recipients. Fortaleza, Ceará, Brazil, 2017.

\begin{tabular}{|c|c|c|c|c|}
\hline & $\begin{array}{l}\text { Hours spent per } \\
\text { day on care for the } \\
\text { elderly }\end{array}$ & $\begin{array}{l}\text { Hours spent per day } \\
\text { on discretionary } \\
\text { activities }\end{array}$ & $\begin{array}{l}\text { Hours spent per } \\
\text { day on activities } \\
\text { of caregiver }\end{array}$ & $\begin{array}{l}\text { Hours spent per day } \\
\text { on recuperation }\end{array}$ \\
\hline $\begin{array}{l}\text { Perceived burden score } \\
\text { of caregiver }\end{array}$ & $\begin{array}{l}r h_{0}=0.307 \\
p=0.030 *\end{array}$ & $\begin{array}{l}r h o=-0.025 \\
p=0.863\end{array}$ & $\begin{array}{l}r h_{0}=0.006 \\
p=0.964\end{array}$ & $\begin{array}{l}r h o=-0.223 \\
p=0.120\end{array}$ \\
\hline $\begin{array}{l}\text { Pfeffer functionality scale } \\
\text { score of recipients of care }\end{array}$ & $\begin{array}{l}r h_{0}=0.458 \\
p=0.001^{*}\end{array}$ & $\begin{array}{l}r h o=0.038 \\
p=0.792\end{array}$ & $\begin{array}{l}r h o=-0.009 \\
p=0.496\end{array}$ & $\begin{array}{l}r h o=-0.086 \\
p=0.554\end{array}$ \\
\hline $\begin{array}{l}\text { Clinical Dementia Rating } \\
\text { (CDR) score of care recipients }\end{array}$ & $\begin{array}{l}r h_{0}=0.433 \\
p=0.002^{*}\end{array}$ & $\begin{array}{l}r h o=-0.078 \\
p=0.592\end{array}$ & $\begin{array}{l}r h o=-0.007 \\
p=0.963\end{array}$ & $\begin{array}{l}r b_{0}=-0.217 \\
p=0.130\end{array}$ \\
\hline
\end{tabular}

* Spearman Test; $p \operatorname{sign}<0.05$.

\section{DISCUSSION}

The present study investigated relationships between the use of time of family caregivers of elderly persons with dementia, considering the circumstances under which care was provided. The caregivers were mainly women, who lived and cared for parents and spouses with moderate to severe levels of physical and cognitive dependence. They reported that most of their daily time was spent on obligatory care activities for the elderly and on caring for the family, home, and themselves, especially in the morning. Next came discretionary activities, performed primarily at night and, lastly, recuperation activities, which occurred mainly in the early hours. In the morning and the afternoon, caregivers spent significantly more time caring for the elderly than on discretionary activities and obligatory activities for the home, family, and self-care. In the early hours, significantly more time was spent on recuperation and caring for the elderly than on obligatory activities in the life of the caregiver and self-care activities. The greater the dependence of the care recipients, the more time spent on care and the greater the perceived burden of caregivers.

Due to cultural and historical determinisms that match the sample of this study with those of other studies carried out in Brazil and abroad, the sample population was essentially female, aged 50 years or over, composed of daughters and spouses of the care recipients, with whom they resided and of whom they were the main caregivers ${ }^{5,6,30}$. Even in countries with a greater tradition of formal care for the elderly than Brazil, family caregivers are mainly responsible for the daily care and supervision of elderly people with dementia ${ }^{13}$. Replicating a characteristic of this cohort, which is not necessarily repeated in other countries, the majority did not perform paid work ${ }^{31}$. Mirroring the influence of the locations from where the elderly were recruited, the level of schooling of the sample was higher than that of the general population of the same age, today, in Brazil and in Fortaleza, State of Ceará ${ }^{32}$.

It was observed that more time was dedicated to take care of parents than of spouses, probably because the parents in the study are older and, consequently, have more physical and mental health impairments than their spouses. Most care recipients had moderate to severe dementia and an intermediate level of functional dependence. These data replicate those of Hajek et al. ${ }^{11}$ and Haro et al. ${ }^{21}$, in which the time the informal caregiver devotes to care increases proportionally with the increased severity of dementia. The authors state that the time devoted to care may vary according to the needs of the care recipient, the stage of the disease and the caregiver's circumstances and burden. They also consider that all categories of informal care time related to assisting with BADL, IADL and supervision are related to the severity of dementia, as well as the total time devoted to care.

Discretionary activities, which mainly involve leisure and social activities, are the first to be sacrificed for more full-time dedication to care, generating a sense of loss of freedom and privacy in family caregivers. Schüz et al. ${ }^{18}$ observed that caregivers who perceived a restriction in their leisure 
activities suffered more from the effects of stress and burden of care on their mental health. They observed a relationship between stress and burden, with repercussions such as depressive and anxiety symptoms, and a lower satisfaction with life. These can be attenuated through participation in group social activities. Informal caregivers of elderly people with dementia can benefit from leisure and social activities, as well as from self-help groups.

Considering that the majority of caregivers were individuals with a relatively high socioeconomic status by the standards of Fortaleza, and especially considering the local culture, the number of caregivers who described having help from a domestic worker when providing care was noticeably low. Although not hired to provide care, which would have yielded a negative response, in practice these individuals perform care tasks as an extension or a natural consequence of their roles. The probable lack of qualifications of these workers, who were generally low-income and low-educated women, coupled with the shortage of formal support services, ratifies the culture of the use of domestic staff in care activities $^{9}$ and contributes to a lack of fair treatment and consequently avoidance of the issue of the professionalization of family care of the elderly.

The data from present study replicate others from literature on the subjective and objective burden associated with the time spent caring for relatives with dementia, considering sociodemographic characteristics, the context of care and the number of hours spent providing care. Most caregivers were women who cared for elderly people with physical and cognitive dependence, women and men who spent more hours caring for others than for themselves, and people who lacked time to rest and dedicate to themselves ${ }^{4,15,19,33}$. The time spent caring for an elderly person with dementia unfolds as part of a daily life divided into multiple tasks and roles that absorb the time of the caregiver and tend to generate dissatisfaction and burden. Pereira and Soares ${ }^{34}$ observed a high prevalence of depression and poor sleep quality in caregivers of elderly patients diagnosed with Alzheimer's and Parkinson's diseases.

Comparing the daily time spent on activities performed in the four periods of the day, it was found that the caregivers invested their time firstly in activities of care and secondly in discretionary activities partly realized at the same time as their care and nursing duties. Even so, discretionary activities were significantly more frequent than those dedicated to the care of the home, to self-care and to recuperation activities. There exist overlap between the tasks of caring for the elderly, domestic and personal tasks of the caregiver, tasks of supervision, and tasks performed concurrently by other family members and caregivers. The lack of accuracy of the data in this respect can camouflage information about objective and subjective burden and the unmet needs of family caregivers of elderly people with dementia.

According to the surveys by Wimo et al. ${ }^{14}$, Novelli et al. ${ }^{35}$, Vaingankar et al..$^{15}$ and Bauab and Emmel ${ }^{22}$, the time spent on obligatory care prevails over the time spent on other activities, to the detriment of self-care and discretionary activities. It is as if caregivers are oppressed by the role of caregiver, becoming hostage to their dedication. In this light, the question to be answered is whether societies will continue to hold the family solely responsible for caring for elderly persons with physical and cognitive dependence. If on the one hand caregivers have the pleasant possibility of caring for their elderly relatives and, in doing so, accomplish an evolutionary task of high moral and ethical value, on the other, they become a silent victim of care.

It was not possible to measure the time spent on simultaneous tasks, nor the time provided by domestic staff and formal services, which probably caused an overestimation of the hours devoted to care. This problem was considered by Neubauer et al. ${ }^{8}$, who calculated a distortion of $14 \%$ caused by the disregard of the action of other caregivers in the domestic scenario. Although there is no quantitative data relating to this concept, in Brazil, the role of domestic workers in the care of dependent elderly tends to be seen as part of their household chores?.

The results are not exactly new or surprising. It is understandable that the higher the level of dependency of the care recipient, the greater the time dedicated to their care and the greater the burden on caregivers. The main limitations of the study are: the absence of greater variability in the levels of physical and cognitive dependence of care recipients; the lack of quantification and qualification of assistance from 
domestic helpers and other sources of support; the absence of quantification of daily and weekly time spent on paid work and the lack of a record of the type of occupation exercised by caregivers.

The fact that this study is the first in Brazil to offer data that promotes the understanding of how family caregivers of elderly people with dementia use their time and how this use covariates not only with the degree of physical and cognitive dependence of the care recipients, but also the characteristics of caregivers and their families, and the social norms of gender and age in force at a given historical moment. Also worthy of note is the providing of a new and objective perspective for the consideration of criteria of hiring and remuneration of professional caregivers of the elderly, the addressing of which is long overdue considering the reality of aging in Brazil.

\section{CONCLUSION}

The present study showed that the greater the physical and cognitive dependence of the elderly care recipients, the more time was devoted to care on a daily basis, the less time the family caregivers dedicated to themselves and their family and the greater the sense of burden associated with providing

\section{REFERENCES}

1. Moss MS, Lawton MP, Kleban MH, Duhamel L. Time use of caregivers of impaired elders before and after institutionalization. J Gerontol [Internet]. 1993 [acesso em 22 set. 2015];48(3):102-11. Disponível em: https://www.ncbi.nlm.nih.gov/pubmed/8482826

2. Moss MS, Lawton MP. Time budgets of older people: a window on four life styles. J Gerontol [Internet]. 1982 [acesso em 22 set. 2015];37(1):115-23. Disponível em: http://doi.org/10.1093/geronj/37.1.115

3. Van den Berg B, Spauwen P. Measurement of informal care: an empirical study into the valid measurement of time spent on informal caregiving. Health Econ [Internet]. 2006 [acesso em 01 maio 2017];15(5):447-60. Disponível em: http://doi. org/10.1002/hec.1075 care. This knowledge may help professionals who work with the elderly population improve the focus of educational interventions and psychosocial support to informal caregivers of the elderly, in addition to placing emphasis on the stress of caregivers and the need to offer them affective assistance. The new perspective derived from the reported data includes the realization of interventions focused on the development of skills to plan and organize the amount of daily time dedicated to the care of the elderly; the introduction of sufficient discretionary activities to meet the interests of caregivers; and the inclusion of leisure and rest activities and activities related to the life of the family and the caregivers. It includes motivating and training caregivers to delegate tasks, to obtain and accept informal and formal help, and to activate formal mechanisms of assistance. These are sensitive aspects of the current scenario of family care for the elderly, which will be increasingly important in the years to come, when the number of elderly people with dementias will increase sharply, due to the increase in population longevity. Caring for the circumstances of caregiving, among which are the time dedicated to the tasks of supporting an elderly person with physical and cognitive dependencies, can improve the physical and psychological well-being of family caregivers, benefiting not only them, but also those who receive their care.

4. Oldenkamp M, Hagedoorn M, Slaets J, Stolk R, Wittek R, Smidt N. Subjective burden among spousal and adult-child informal caregivers of older adults: results from a longitudinal cohort study. BMC Geriatr [Internet]. 2016 [acesso em 22 set. 2017];16:1-22. Disponível em: http://doi. org/10.1186/s12877-016-0387-y

5. Tomomitsu MRSV, Perracini MR, Neri AL. Fatores associados à satisfação com a vida em idosos cuidadores e não cuidadores. Ciênc Saúde Colet [Internet]. 2014 [acesso em 22 set. 2017],19(8):342940. Disponível em: http://doi.org/10.1590/141381232014198.13952013 
6. Bednarek A, Mojs E, Krawczyk-Wasielewska A, Głodowska K, Samborski W, Lisiński P, et al. Correlation between depression and burden observed in informal caregivers of people suffering from dementia with time spent on caregiving and dementia severity. Eur Rev Med Pharmacol Sci [Internet]. 2016 [acesso em 22 set. 2017];20(1):59-63. Disponível em: https://www.ncbi.nlm.nih.gov/pubmed/26813454

7. Farina N, Page TE, Daley S, Brown A, Bowling A, Basset T, et al. Factors associated with the quality of life of family carers of people with dementia: A systematic review. Alzheimers Dememt [Internet]. 2017 [acesso em 22 set. 2017];13(5):572-81. Disponível em: http://doi.org/10.1016/j.jalz.2016.12.010

8. Neubauer S, Holle R, Menn P, Grossfeld-Schmitz $\mathrm{M}$, Graesel E. Measurement of informal care time in a study of patients with dementia. Int Psychogeriatr [Internet]. 2008 [acesso em 05 fev. 2017];20(6):116076. Disponível em: http://doi.org/10.1017/ S1041610208007564

9. Camarano AA, Kanso K. Como as famílias brasileiras estão lidando com os idosos que demandam cuidados e quais as perspectivas futuras?: a visão mostrada pelas PNADs. In: Camarano AA, editora. Cuidados de longa duração para a população idosa: um novo risco social a ser assumido? Rio de Janeiro: IPEA; 2010. p. 93-112.

10. Taylor DH Jr, Kuchibhatla M, Østbye T. Trajectories of caregiving time provided by wives to their husbands with dementia. Alzheimer Dis Assoc Disord [Internet]. 2008 [acesso em 05 fev. 2017];22(2):131-

6. Disponível em: http://doi.org/10.1097/

WAD.0b013e31815bebba

11. Hajek A, Brettschneider C, Ernst A, Posselt T, Wiese B, Prokein J, et al. Longitudinal predictors of informal and formal caregiving time in communitydwelling dementia patients. Soc Psychiatry Psychiatr Epidemiol [Internet]. 2016 [acesso em 22 set. 2017];51(4):607-16. Disponível em: http://doi. org/10.1007/s00127-015-1138-7

12. Alzheimer's Disease International. World Alzheimer Report: the global impact of dementia: an analysis of prevalence, incidence, cost and trends [Internet]. London: ADI; 2015 [acesso em 19 nov. 2015]. Disponível em: http://www.alz.co.uk/research/worldreport-2015

13. Carvalho EB, Neri AL. Uso do tempo por cuidadores familiares de idosos com demência: revisão integrativa. Rev Bras Enferm [Internet]. 2018 [acesso em 11 jun. 2018];71(Suppl 2):893-904. Disponível em: http://doi.org/10.1590/0034-7167-2017-0268
14. Wimo A, Jonsson L, Zbrozek A. The Resource Utilization in Dementia (RUD) instrument is valid for assessing informal care time in community-living patients with dementia. J Nutr Health Aging [Internet]. 2010 [acesso em 22 set. 2017];14(8):685-90. Disponível em: http://doi.org/10.1007/s12603-010-0316-2

15. Vaingankar JA, Chong SA, Abdin E, Picco L, Jeyagurunathan A, Zhang Y, et al. Care participation and burden among informal caregivers of older adults with care needs and associations with dementia. Int Psychogeriatr [Internet]. 2016 [acesso em 22 set. 2017];28(2):221-31. Disponível em: http://doi. org/10.1017/S104161021500160X

16. Feldman HH, Van Baelen B, Kavanagh SM, Torfs KE. Cognition, function, and caregiving time patterns in patients with mild-to-moderate Alzheimer disease: a 12-month analysis. Alzheimer Dis Assoc Disord [Internet]. 2005 [acesso em 22 set. 2017];19(1):29-36. Disponível em: http://doi. org/10.1097/01.wad.0000157065.43282.bc

17. Stevens AB, Coon D, Wisniewski S, Vance D, Arguelles S, Belle S, et al. Measurement of leisure time satisfaction in family caregivers. Aging Ment Health [Internet]. 2004 [acesso em 22 set. 2017];8(5):450-9. Disponível em: http://doi.org/10.10 80/13607860410001709737.

18. Schüz B, Czerniawski A, Davie N, Miller L, Quinn MG, King C, et al. Leisure time activities and mental health in informal dementia caregivers. Appl Psychol Health Well Being [Internet]. 2015 [acesso em 22 set. 2017];7(2):230-48. Disponível em: http://doi. org/10.1111/aphw.12046

19. Hughes TB, Black BS, Albert M, Gitlin LN, Johnson DM, Lyketsos CG, et al. Correlates of objective and subjective measures of caregiver burden among dementia caregivers: Influence of unmet patient and caregiver dementia-related care needs. Int Psychogeriatr [Internet]. 2014 [acesso em 22 set. 2017];26(11):1875-83. Disponível em: http://doi. org/10.1017/S1041610214001240

20. Kraijo H, Van Exel J, Brouwer W. The perseverance time of informal carers for people with dementia: results of a two-year longitudinal follow-up study. BMC Nurs [Internet]. 2015 [acesso em 22 set. 2017];14:56. Disponível em: http://doi.org/10.1186/ s12912-015-0107-5

21. Haro JM, Kahle-Wrobleski K, Bruno G, Belger M, Dell'Agnello G, Dodel R, et al. Analysis of burden in caregivers of people with Alzheimer's disease using self-report and supervision hours. J Nutr Health Aging [Internet]. 2014 [acesso em 22 set. 2017];18(7):677-84. Disponível em: http://doi. org/10.1007/s12603-014-0036-0. 
22. Bauab JP, Emmel MLG. Mudanças no cotidiano de cuidadores de idosos em processo demencial. Rev Bras Geriatr Gerontol [Internet]. 2014 [acesso em 22 set. 2017];17(2):339-52. Disponível em: http://doi. org/10.1590/S1809-98232014000200011

23. Pfeffer RI, Kurosaki TT, Harrah Jr. CH, Chance JM, Filos S. Measurement of functional activities in older adults in the community. J Gerontol [Internet]. 1982 [acesso em 16 out. 2015];37(3):323-9. Disponível em: http://doi.org/10.1093/geronj/37.3.323

24. Sanchez MAS, Correa PCR, Lourenço RA. Crosscultural adaptation of the "Functional Activities Questionnaire - FAQ" for use in Brazil. Dement Neuropsychol [Internet]. 2011 [acesso em 16 out. 2015];5(4):322-7. Disponível em: http://doi. org/10.1590/S1980-57642011DN05040010

25. Dutra MC, Ribeiro RS, Pinheiro SB, Melo GF, Carvalho GA. Acurácia e confiabilidade do questionário de Pfeffer para a população idosa brasileira. Dement Neuropsychol [Internet]. 2015 [acesso em 19 nov. 2015];9(2):176-83. Disponível em: http://doi.org/10.1590/1980-57642015DN92000012

26. Morris JC. The Clinical Dementia Rating (CDR): current version and scoring rules. Neurology [Internet]. 1993 [acesso em 16 out. 2015];43(11):2412-4. Disponível em: http://doi.org/10.1212/WNL.43.11.2412-a

27. Montaño MBM, Ramos LR. Validade da versão em português da Clinical Dementia Rating. Rev Saúde Pública [Internet]. 2005 [acesso em 16 set 2015];39(6):912-7. Disponível em: http://doi. org/10.1590/S0034-89102005000600007

28. Zarit SH, Reever KE, Bach-Peterson J. Relatives of the impaired elderly: correlates of feelings of burden. Gerontologist [Internet]. 1980 [acesso em 15 out. 2015];20(6):649-55. Disponível em: http://doi. org/10.1093/geront/20.6.649

29. Scazufca M. Versão brasileira da escala Burden interview para avaliação de sobrecarga em cuidadores de indivíduos com doenças mentais. Rev Bras Psiquiatr [Internet]. 2002 [acesso em 15 out. 2015];24(1):12-7. Disponível em: http://doi. org/10.1590/S1516-44462002000100006
30. Custodio N, Wheelock A, Thumala D, Slachevsky A. Dementia in Latin America: Epidemiological evidence and implications for public policy. Front Aging Neurosc [Internet]. 2017 [acesso em 22 set. 2017];9:1-20. Disponível em: http://doi.org/10.3389/ fnagi.2017.00221

31. Leite BS, Camacho ACLF, Joaquim FL, Gurgel JL, Lima TR, Queiroz RS. A vulnerabilidade dos cuidadores de idosos com demência: estudo descritivo transversal. Rev Bras Enferm [Internet]. 2017 [acesso em 11 jun. 2018];70(4):714-20. Disponível em: http:// doi.org/10.1590/0034-7167-2016-0579

32. Instituto Brasileiro de Geografia e Estatística. PNAD Contínua 2016: 51\% da população com 25 anos ou mais do Brasil possuíam apenas o ensino fundamental completo. Agência de Notícias do IBGE [Internet]. 21 dez. 2017 [acesso em 11 jun. 2018]. Disponível em: https://agenciadenoticias.ibge.gov.br/ agencia-sala-de-imprensa/2013-agencia-de-noticias/ releases/18992-pnad-continua-2016-51-da-populacaocom-25-anos-ou-mais-do-brasil-possuiam-apenas-oensino-fundamental-completo

33. Shahly V, Chatterji S, Gruber MJ, Al-Hamzawi A, Alonso J, Andrade LH, et al. Cross-national differences in the prevalence and correlates of burden among older family caregivers in the World Health Organization World Mental Health (WMH) Surveys. Psychol Med [Internet]. 2013 [acesso em 22 set. 2017];43(4):865-79. Disponível em: http://doi. org/10.1017/S0033291712001468

34. Pereira LSM, Soares SM. Fatores que influenciam a qualidade de vida do cuidador familiar do idoso com demência. Ciênc Saúde Colet [Internet]. 2015 [acesso em 22 set. 2017];20(12):3839-51. Disponível em: http://doi.org/10.1590/1413-812320152012.15632014

35. Novelli MMPC, Nitrini R, Caramelli P. Cuidadores de idosos com demência: perfil sociodemográfico e impacto diário. Rev Ter Ocup [Internet]. 2010 [acesso em 22 set. 2017];21(2):139-47. Disponível em: http:// doi.org/10.11606/issn.2238-6149.v21i2p139-147 